\title{
POKOK-POKOK PIKIRAN DAN STRATEGI DALAM PENANGGULANGAN KEJAHATAN BISNIS
}

Oleh :

\section{Indrati Rini}

Aktivitas bisnis di Indonesia terkait erat dengan kebijaksanaan politis pemerintah, termasuk juga penanggulangan kejahatan bisnis Deviance Behavior merupakan fenomena yang melekat dalam praktek bisnis, dimana terjadi pelanggaran atau kejahatan yang tidak bertentangan dengan peraturan perundang-undangan tetapi juga bertentangan dengan moral dan etika masyarakat strategi penanggulangan terhadap kejahatan bisnis dapat dilakukan dengan cara-cara pemberdayaan komisi pengawas persaingan usaha serta badan penyelesaian sengketa konsumen, konsisten pada penegakan hukum, memotivasi persaingan bisnis untuk mencapai daya saing yang baik, pemberian informasi bisnis pada masyarakat.

\section{Pendahuluan}

ada dan marakat bisnis senantiasa
Eksistensinya merebak, baik bersifat lokal, regional, nasional maupun global. Tak ada satupun masyarakat di dunia ini yang terlepas dari business practice. Sayangnya tak semua traksaksi yang dilakukan berlangsung secara normal dan wajar, kerap kali dijumpai adanya unfair business practice.

Aktivitas bisnis di Indonesia terkait erat dengan kebijaksanaan politis Pemerintah, sebagaimana tertuang dalam GBHN Tahun 19992004 , bidang ekonomi bahwa akan dikembangkan perekonomian yang berorientasi global, sesuai dengan kemajuan teknologi dengan membangun keunggulan kompetitif

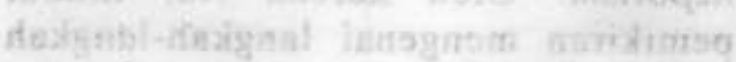
dari keunggulan komparatif berdasarkan kompetensinya.

Praktek bisnis kotor hampir melanda bidang-bidang bisnis yang diminati masyarakat, diantaranya pembajakan karya atas kekayakaan intelektual, kejahatan komputer, penyalahgunaan korporasi dan berbagai tindak kriminal bisnis lainnya. Fenomena ini tidak terlepas dari munculnya peluang untuk melakukan bisnis yang menyimpang, di samping faktor orang sebagai SDM dan faktor rapuhnya kontrol masyarakat dan pemerintảh, serta belum sepenuhnya law enforcement dilakukan dengan baik dan benar.

Rintangan dalam bisnis seringkali tidak dapat diantisipasi dan diatasi oleh para pelaku bisnis, baik berupa natural barrier maupun 
rintangan yang diciptakan oleh kebijaksanaan pemerintah. Untuk menembus rintangan-rintangan bisnis tersebut, dapat bermunculan kejahatan atau persaingan antar pelaku bisnis, baik secara jujur dan sehat maupun yang menyimpang.

Persaingan bisnis yang ketat, baik domestik maupun global dapat mendorong peningkatan efisiensi dan produktivitas, namun konsentrasi pasar yang tinggi merupakan peluang terjadinya corruption, collution and nepotism. Oleh karena itu, timbul pemikiran mengenai langkah-langkah dan strategi apa dan dalam kondisi yang bagaimana dapat dilakukan upaya-upaya dalam menanggulangi kejahatan bisnis?

\section{Kejahatan Bisnis}

Perilaku yang menyimpang, yang dikenal pula sebagai deviance behavior, merupakan fenomena yang melekat dalam praktek bisnis. Istilah penyimpangan yang acapkali berkembang menjadi pelanggaran atau kejahatan, tidak saja bertentangan dengan peraturan perundang-undangan yang berlaku, tetapi juga bertentangan dengan moral dan etika yang dihormati masyarakat.

Istilah business crime, sering digunakan dalam konteks yang mirip bahkan cenderung sama dengan syndicate crime, organized crime, group criminaliteit, atau white collar crime. Di samping itu juga sering terdengar sebutan lain, diantaranya occupational deviance (Quinney, 1964), official deviance (Douglass \& Johnson, 1977), occupational crime (Green, 1990), corporate \& governmental deviance (Erman \& Lundman, 1978)

Selanjutnya ditemukan pula penamaan lain, diantaranya illegal corporate behavior (Clinard et. al, 1979) dan elite deviance (Simon \& Eitzen, 1982), serta economic crime (Wickmand \& Dailey, 1982).

Dari berbagai penyebutan tersebut, yang penting adalah hakekat dari kejahatan bisnis itu sendiri, yaitu suatu prilaku yang menyimpang yang dilakukan oleh pelaku bisnis, demi mendapatkan keuntungan, baik materiil maupun immateriil, dengan melanggar ketentuan-ketentuan bisnis.

Kejahatan bisnis, sebenarnya bukanlah hal yang baru terjadi, sebagaimana yang terjadi di Amerika Serikat, bahwa business crimes are not a recent phenomenon, since the dawn of trade, merchants have tried to gain an advantage in their dealings, historically, such as efforts have often developed into categories of behavior variously labeled, unfair, improper and illegal (Marshall B. Clinard \& Petter C. Yeager, 1980), Kemudian pada akhir abad 19 dan awal abad 20 terdapat kekuasaan monopolistik dan penyimpangan oleh perusahaan- 
perusahaan besar yang mengarah pada kejahatan bisnis.

Dalam kejahatan bisnis yang hampir dapat diidentikkan dengan coporate crime, secara aktual merupakan kejahatan yang terorganisir yang terjadi dalam konteks hubungan yang komplek, diantara harapanharapan dewan direksi, eksekutif dan manajer pada satu sisi, dan diantara perusahaan-perusahaan induk, divisidivisi dan cabang-cabangnya pada sisi yang lain.

Para peneliti di Amerika Serikat (Ralp Salerno, et. al, 1967) telah mencoba untuk menemukan pola kejahatan terorganisi, sebagaimana dipercaya sebagai classic pattern of organized crime. Dalam hal ini ada dua macam penyimpangan hukum yang berbeda. Tipe yang pertama adalah strategic \& tactical crimes, seperti penyuapan, monopoli, korupsi ataupun pembunuhan. Tipe yang kedua adalah kejahatan-kejahatan terorganisir yang mendominasi dan mengontrol aktivitasaktivitas bisnis illegal, diantaranya narkotik, penggelapan, penyelundupan, prostitusi ataupun peredaran minuman keras.

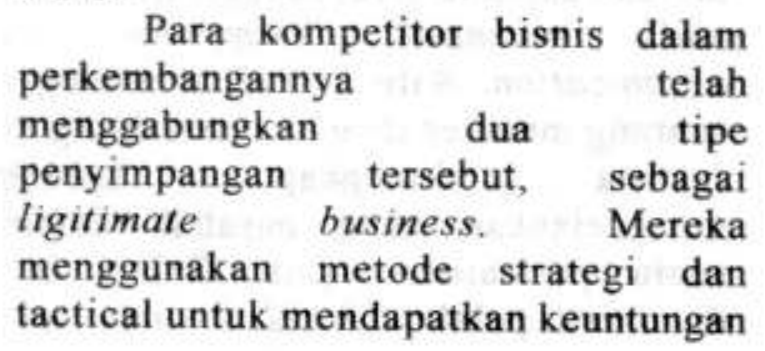

yang istimewa, walaupun keuntungannya illegal. Kegiatannya meliputi dealer mobil, restoran, pabrik, hiburan malam, penjualan makanan dan asosiasi-asosiasi bisnis lainnya, termasuk di dalamnya yaitu perbankan, entertainment, perhotelan, asuransi, real estate, perburuhan, dan perkreditan serta financial securities.

Persaingan tidak wajar atau kompetisi tidak sehat, acapkali menjelma menjadi suatu jenis tindak kriminal, baik yang disebut pelanggaran ataupun kejahatan.

Pelaku-pelaku bisnis di Indonesia, baik berasal dari pemerintah, swasta nasional maupun swasta asing acapkali terlihat dalam lingkaran transaksi yang tidak sehat. Perusahaan negara dalam bentuk BUMN maupun BUMD, dengan wadah Perjan, Perum maupun PT. Persero, di satu sisi dan di sisi lain adalah pelaku bisnis swasta asing dan nasional, dengan bentuk perorangan, $\mathrm{CV}$ ataupun Perseroan Terbatas, serta Koperasi dan Yayasan

Perusahaan-perusahaan asing yang bermitra dengan swasta nasional, lazimnya berbentuk joint venture, dengan berbagai lisensi, dengan dalih franchising atau transfer of technology, sebagai pelaku bisnis berpeluang mempunyai kekuasaan yang monopolistik dan terlibat KKN, sehingga berpotensi sebagai pelanggaran hukum bisnis. 
Kejahatan bisnis merupakan delik atau tindak pidana yang tunduk pada larangan dan sanksi pidana. Sebagai pelaku tindak pidana, tentu saja mereka harus memenuhi unsur utama, yaitu unsur subyektif dan obyektif (Satochid Kartanegara, 1986).

Unsur subyektif meliputi niat dan kesalahan, sedangkan unsur obyektif terdiri dari perbuatan dan akibat hukumnya. Penjahat bisnis baru dapat dipidana, apabila dapat dipertanggung jawabkan atas perbuatan yang dilakukannya. Ajaran Kausalitas menjadi landasan utamanya.

Pelaku bisnis yang terbukti bersalah melakukan, persaingan curang di samping dapat dijerat sanksi pidana dapat pula dipertanggung jawabkan/digugat secara perdata (responsibility and liability in private law). Mereka dapat dituntut telah melakukan suatu perbuatan yang melanggar hukum (onrechtmatige daad). Melanggar hukum dimaksudkan sebagai bertentangan dengan hukum dalam arti yang lebih luas daripada Undang-Undang (Pompe dalam Roeslan Saleh, 1981).

Pelaku bisnis yang melanggar hukum, sebenarnya telah melakukan perbuatan yang bertentangan dengan hak orang lain, kewajiban hukumnya sendiri, dan kesusilaan serta ketertiban umum. Intinya atas perbuatannya tersebut, mereka harus mengganti kerugian yang diderita pihak lain.
Pihak lain ini dapat berbentuk perorangan, ataupun badan hukum, baik bersifat publik atau privat serta masyarakat sebagai pengguna produk barang dan jasa yang dikenal sebagai konsumen. Kerugian yang dapat dituntut baik, bersifat materiil maupun immateriil. Keberhasilan untuk mendapatkan ganti kerugian dapat membuktikan adanya unsur kesalahan pengusaha. Hal ini bukanlah pekerjaan yang gampang, sebab waktu, tenaga, pikiran dan modal menjadi tumpuannya.

\section{Fenomena Penyimpangan}

Penyimpangan bisnis muncul, tentu saja terkait dengan konteks lingkungan sosialnya. Manusia sebagai human resources adalah pelaku utamanya. Baik dalam birokrasi maupun bisnis, penyimpangan dapat terjadi sebagai fenomena yang harus dicermati, baik dari aspek ekonomi, politik, sosial budaya, iptek dan aspekaspek lainnya.

Kehadiran pelaku bisnis, baik sebagai insiders atau outsiders, harus dilihat secara jeli dan teliti. Boleh jadi mereka dapat terlibat sebagai the latent and potential criminals in organization. Kita pernah mendengar seorang manajer treasury bank asing di Jakarta ditangkap, karena menggelapkan uang nasabah dalam suatu permainan valas. Dalam ha! demikian pelaku bisnis di Indonesia 
dapat terimbas dari arus bisnis yang mendunia.

Dunia ini terlihat semakin menyatu dan seolah tanpa batas (globalizad and borderless). Perkembangan di bidang ilmu, teknologi, hukum, politik, dan ekonomi, dapat memicu tumbuh kembangnya kejahatan bisnis. Kejahatan pada dasarnya bersifat konvensional dan kontemporer. Kejahatan jenis kontemporer inilah dikenal sebagai kejahatan berdimensi canggih dan modern, di antaranya kejahatan-kejahatan narkoba, komputer, perbankan, perasuransian, perpajakan dan sebagainya.

Indonesia bagaimanapun juga sebagai pelaku bisnis Internasional akan berpengaruh oleh perkembangan global dalam bisnis. Sebuah perusahaan kimia raksasa Montedison Amerika Serikat, ditemukan tak berlisensi dalam mengelola software komputer. Memang ada GATT, peraturan-peraturan WTO, TRIP's dan yang lainnya, namun tak mampu membendung makin derasnya arus penjiplakan atau pembajakan karyakarya intelektual.

Kasus-kasus mengenai hak cipta, paten dan merek, memang telah terakomodir dalam Undang-Undang Nomor 12, 13 dan 14 Tahun 1997. Juga telah diratifisir lima konvensi Internasional, diantaranya adalah WIPO Copyright Treaty, Paris and
Berne Convention, Patent Coorporation Treaty dan Trade Made Law. Yang terjadi Indonesia justru menjadi negara terbesar kedua di Asia dalam penjiplakan hak milik intelektual.

Pelanggaran HAKI tergolong kejahatan yang bersifat Mukti Nasional, karena menembus bisnis global. Dalam hal ini Indoneia oleh Amerika Serikat telah ditempatkan dalam priority watch list, sejajar dengan Cina, Bulgaria, Israel, Brunei, Afrika Selatan, Meksiko, maupun Korea (Dirjen Hukum dan Perundangundangan, 2000).

Fenomena sejumlah penjamin (guarantor) PT. Bentoel terusik oleh para krediturnya, akibat bisnis penjaminan. Dalam kredit perbankan, kerapkali terjadi penyimpangan, dimana pejabat yang berkuasa atau penguasa bonafid memberikan memo atau katabelece bagi kemudahan pencairan kredit, padahal penjaminan dapat bersifat personal guarantee atau corporate guarantee, yang mengikat seluruh harta penjamin.

Suatu saat terdengar Dirut Garuda diduga telah menerima komisi US\$ 4,5 juta, juga menyangkut pejabatpejabat dan para konglomerat ternama. Uang komisi tersebut dikemanakan, fenomena ini lekat dengan money laundering. Uang komisi illegal tersebut dicuci ke luar negeri, dan dampaknya banyak timbul bank gelap, 
perjudian lewat pacuan kuda dan praktek kotor lainnya.

Di dalam Bursa Komoditi Indonesia, dapat timbul future trading, dimana perdagangan berjangka atas komoditas tertentu, diantaranya tekstil, kopi dan karet. Fenomena ini sebagian ada yang menganggap sebagai judi, tetapi sebagian lagi menolaknya yang terjadi adalah memprediksi harga, bukan untung-untungan. Perusahaanperusahaan ini sebagai agen bursa Tokyo yang hanya berbekal selembar ijin usaha Bisnis ini mendorong terjadinya berbagai penggelapan dan penipuan, sebab yang diperdagangkan bukan hasil komoditi Indonesia.

Fenomena lain yang menarik adalah bahaya virus komputer Diantaranya adalah virus Michelangelo, karena virus ini diprogramkan untuk mengacaukan jaringan informasi. Pembajakan atau penggandaan program dan hingar bingarnya arus informasi, menyebabkan virus ini meluas. Dalam hal ini yang jelas ada penjahat dan korbannya. Di Singapura ada National Computer Board, di Amerika Serikat ada Service's Operatio Sun Devil. Kegiatan mereka yang utama adalah memberi peringatan dan membantu penegak hukum dalam menanggulangi kejahatan kompouter. Di Belanda sejak tahun 1982 telah ditentukan bahwa data komputer dianggap sebagai barang. Di Indonesia memang perangkat hukum agak minim, boleh jadi hanya berdasarkan KUHP dan peraturanperaturan $\mathrm{HAKI}$

Pada akhir-akhir inı di Indonesia yang lagi gencar-gencarnya dikumandangkan Slogan di TV Ayo Sekolah, ternyata telah menggelitik orang-orang tak bertanggung jawab berbisnis ria di bidang pendidikan. Ironis sekali, tetapi ini fenomena aktual yang harus ditanggulangi atau diantisipasi. akibat derasnya dan bersatunya sistem pendidikan nasional antara mitra nasional dan asing dijadikan ajang bisnis yang memalukan. Tangan-tangan kotor yang haus keuntungan haram berkeliaran hampir di setiap sudut kota.

\section{Strategi Penanggulangan}

Praktek bisnis tidak akan menarik, tanpa adanya penyimpangan hukum Betapapun sulit menanggulanginya, namun ada strategi tertentu yang dapat dilakukan.

Pelaku bisnis menyimpang, boleh jadi tidak diketahui oleh penegak hukum, tidak diadili atau tidak dipidana. Untuk itu, sesuai dengan eksistensi hukum, terutama Hukum Bisnis harus konsisten ditegakkan, tanpa melakukan diskriminasi bagi para pelakunya

Komisi pengawas persaingan usaha diberdayakan dalam menangani praktek monopoli, monosponi, persengkongkolan dalam produksi dan 
pemasaran, serta persaingan tidak sehat dalam bisnis. Komisi ini tidak secara pasif menunggu pengaduan, tetapi secara aktif mencari dan menelusuri praktek-praktek bisnis terlarang tersebut, diantaranya memberikan sanksi administratif pembatalan perjanjian, atau pembatalan penggabungan atau peleburan perusahaan.

Pengadilan sebagai institusi pemberi keadilan benar-benar fungsional dalam memvonis praktek bisnis terlarang, berdasarkan KUHP UU No. 5 Tahun 1999 dan berbagai peraturan lainnya. Putusan pengadilan dapat berupa hukuman pokok denda atau kurungan, ditambah pidana tambahan, diantaranya pencabutan izin usaha, larangan kepada pelaku bisnis yang bersalah menduduki jabatan direksi atau komisaris dan yang lainnya.

Strategi lain yang dapat
dilakukan adalah mengurangi maraknya KKN, berdasarkan UU No. 28 Tahun 1999. Penyelenggaraan negara yang bersih dari $\mathrm{KKN}$, akan menimbulkan keengganan pelaku bisnis untuk berkolusi, ataupun mendorong pejabat untuk korupsi dan nepotisme.

Buruh atau karyawan yang under paid, tidak jelas job description yang harus dilakukannya, dieliminir, sehingga tertutup peluang untuk memberikan atau menjual informasi bisnis ke pesaing perusahannya. Oleh karena itu, perlu pencegahan dan peningkatan fasilitas dan gaji, serta pengawasan yang ketat.

Pemerintah Indonesia hendaknya mendorong persaingan domestik maupun global untuk efisiensi produk dan pemasaran, sehingga mencapai daya saing yang baik. BUMN/D sebagai perusahaan negara tidak merintangi persaingan bisnis yang sehat. Oleh karena itu, pemerintah harus mengurangi bahkan menghilangkan rintangan alamiah bisnis dan rintangan kebijaksanaan pemerintah di berbagai sektor perekonomian.

Sejalan dengan pembangunan ekonomi nasional pada era globalisasi ini, maka perlindungan bagi konsumen maupun pelaku usaha hendaknya seimbang. Para pelaku usaha menghindari larangan menjual/memproduksi barang dan jasa yang merugikan konsumen atau penguasaha lainnya. Oleh karena itu, berdasarkan UU No. 8 Tahun 1999, Badan Penyelesaian Sengketa Konsumen benar-benar berfungsi, dalam menjatuhkan sanksi administrasi di samping putusan pengadilan yang adil.

Peranan intelijen bisnis, seperti di Amerika Serikat perlu digalakkan, yang terhimpun dalam berbagai institusi intel bisnis. Dalam mengantisipasi kejahatan bisnis, ada 
baiknya sarana ini didukung, baik dilakukan oleh pemerintah maupun swasta secara profesional. Pusat Data Bisnis Indonesia atau Surindo Utama, serta survey research Indonesia pada dasarnya melakukan aktivitas intel bisnis atau sebagai lembaga Research and Development.

Strategi lain yang dapat diterapkan adalah pemberian informasi bisnis seluas-luasnya kepada masyarakat, institusi pemerintah atau swasta dapat bergandeng tangan dalam menanggulangi praktek-praktek bisnis terlarang. Dengan mendudukkan masyarakat pada posisi pengguna barang dan jasa, pengontrol praktek bisnis, sekaligus pemberi masukan yang bermanfaat kepada pemerintah dan perusahaan-perusahaan apabila menemui aktivitas yang merugikan bangsa dan negara, dan tercapainya Indonesia yang damai dan sejahtera.

\section{Penutup}

Praktek bisnis menyimpang merupakan fenomena yang tidak mudah ditelusuri dan amat kompleks konteks lingkungan sosialnya. Yang jelas berbagai motif, sikap dan persepsi pelaku bisnis dan keberadaan pelaku bisnis dan keberadaan perangkat hukum dan law enforcer, amat menentukan peluang terjadinya fenomena ini. Di masa sekarang dan yang akan datang tentu akan banyak bermunculan jenis-jenis baru dari kejahatan bisnis, dengan modus operandi yang beragam pula, dengan tempus delicti yang berbeda dan dengan locus delicti, baik di Indonesia maupun di negara-negara lain.

Pada akhirnya, apapun strategi yang dilakukan dalam upaya menanggulangi atau mengantisipasi penyimpangan bisnis, akan terulang pada Sumber Daya Manusianya. Oleh karena itu, pendidikan etika, moral dan spiritual bagi pelaku bisnis amatlah diperlukan, sebab hanya manusialah yang dapat berbisnis dengan modal cipta, rasa dan karsanya. Akhirul kalam, rakyat Indonesia sebagai bagian masyarakat dunia, tiada lain harapan yang diimpikan selain terwujudnya kehidupan material dan spiritual yang mapan dan seimbang, niscaya Indonesia akan menjadi negara kuat dan besar yang dihormati oleh bangsanya sendiri dan bangsa lainnya.

\section{DAFTAR PUSTAKA}

\section{A. Hamzah, Delik Penyelundupan Akademi, Pressindo, Jakarta, 1996.}

\section{Allan A. Block, The Business Crime, Westview Press, San Fransisco, 1995}

Andrianus Meliala, Menyingkap Kejahatan Kerah Putih, Pustaka Sinar Baru, Jakarta, 1995. 
ELIPS, Persaingan Usaha dan Hukum yang Mengaturnya, Surabaya, 1999.

J.E. Sahetapy, Kejahatan Kekerasan, Sinar Wijaya, Surabaya, 1983.

Juajir Sumardji, Aspek-Aspek Hukum Franchising dan Perusahaan Transnasional, Citra Aditya, Bandung, 1995.

Marshall B. Clinard, Corporate Ethics and Crime Sage, Publication, London, 1983.

\section{Corporate}

Crime, The Free Press, London, 1985.

Hukum Bisnis, Journal, Jakarta, Volume 6, 1999.

Ketetapan MPR No. IV/MPR/1999 tentang Garis-Garis Besar Haluan Negara 1999-2004.

Undang-Undang No. 5 Tahun 1999 tentang Larangan Praktek Monopoli dan Persaingan Usaha Tidak sehat.

Undang-Undang No. 8 Tahun 1999 tentang Konsumen.
Undang-Undang No. 28 Tahun 1999 tentang Penyelenggaraan Negara yang Bersih dan Bebas dari KKN. 